\title{
Novel therapies against aggressive differentiated thyroid carcinomas
}

\author{
Sara Donato1, Rita Santos ${ }^{1,2}$, Helder Simões ${ }^{1,2}$ \& Valeriano Leite ${ }^{*, 1,2,3}$ \\ ${ }^{1}$ Endocrinology Department, Instituto Português de Oncologia de Lisboa, Francisco Gentil, Lisbon, Portugal \\ ${ }^{2}$ NOVA Medical School/Faculdade de Ciências Médicas, Universidade Nova de Lisboa, Lisbon, Portugal \\ ${ }^{3}$ Unidade de Investigação em Patobiologia Molecular (UIPM), Instituto Português de Oncologia de Lisboa, Francisco Gentil, Lisbon, \\ Portugal \\ *Author for correspondence: vleite@ipolisboa.min-saude.pt
}

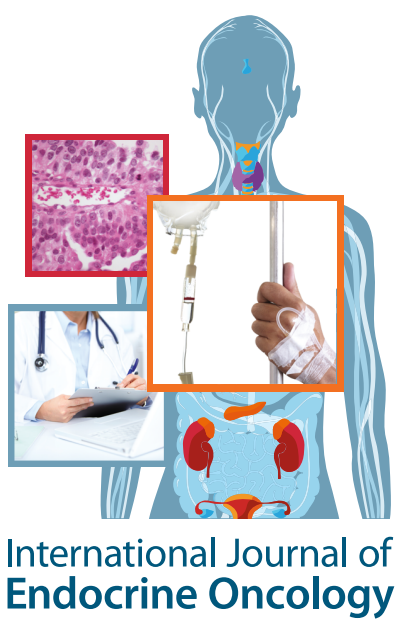

The incidence of thyroid cancer (TC) is increasing. Although the majority of these cancers have a good prognosis, $10 \%$ of these will develop local recurrence and/or distant metastases. Conventional cytotoxic chemotherapy has been largely replaced by molecular-target therapies, but it can still have a role. Two tyrosine kinase inhibitors have been approved for the treatment of advanced differentiated TC. They significantly improve progression-free survival, but at the cost of frequent and potentially serious adverse effects. At the moment, there are multiple clinical trials with other tyrosine kinase inhibitors and other drugs. We present a review of the current standard of care and what is up to come in the treatment of advanced TC.

First draft submitted: 31 July 2017; Accepted for publication: 25 October 2017; Published online: 19 January 2018

Keywords: antineoplastic agents - molecular-targeted therapy - protein kinase inhibitors - thyroid neoplasms/therapy

Thyroid cancer (TC) is a worldwide growing health issue since its incidence is increasing faster than any other neoplasia [1-3]. This fact seems to be related to a greater use of imaging techniques (mainly neck ultrasound) leading to an early diagnosis and treatment of TC. This increase in incidence has no impact in disease-related mortality, which remains at approximately $3 \%[1,4]$. Despite low overall mortality, clinicians face a heterogeneous disease with highly variable survival depending on the tumor histotype and differentiation. Survival rates of TC can be as high as $95 \%$ after 35 years of diagnosis for papillary thyroid carcinoma (PTC) or as low as less than $10 \%$ at 6 months for anaplastic TC (ATC) [5,6].

Most commonly, TC arises from follicular cells ( $>90 \%)$ that can give rise to differentiated TC (DTC), either PTC or follicular TC (FTC) and, less commonly, poorly differentiated TC (PDTC) and ATC [7]. Other histotypes are derived from the parafollicular cells that give rise to medullary TC (MTC) and very uncommonly from stromal cells (sarcoma) and lymphoid tissue (lymphoma) [7-9].

The treatment of DTC relies on the fact that the tumors derived from follicular cells are able to iodine organification and secrete thyroglobulin under stimulation by thyrotropin-stimulating hormone. Iodine retention is promoted by the sodium-iodine symporter, which is expressed in most DTCs [10]. Due to this fact, the majority of DTCs are treatable with surgery and radioiodine (RAI) [11].

A minority (around 10\%), however, will become dedifferentiated, losing the ability to uptake iodine, leading to a rapid progression of local recurrence and/or distant metastases. These patients have a poor prognosis and shorter survival [12]. RAI-refractory TC (RAIRTC) can generally be defined as a tumor that does not concentrate or loses the ability to uptake RAI overtime; RAI concentrates in some lesions but not in others; disease progresses despite RAI uptake [11]. Another definition, although not consensual, is when patients reach $>600 \mathrm{mCi}$ of RAI therapy since the maximum benefit is usually obtained at lower activities [13].

RAIRTC can be treated in several ways. Some patients remain asymptomatic with a stable or minimally progressive disease for years and can be kept under surveillance. Patients with symptomatic lesions (namely, cervical and bone 
lesions) can be treated with local therapies such as radiotherapy or, more recently, radiofrequency ablation therapy in focal metastatic lesions [11].

The objective of this article is to focus in the recent therapies against aggressive, advanced DTC.

\section{Methods}

A medical literature search was conducted between April and June 2017. Resources included MEDLINE via PubMed, EMBASE, Clinical Trials Databases, Cochrane Library and selected references cited in other articles. We used the controlled language of each database.

The search query was (Novel OR Recent OR Advances OR New) AND (therapy OR treatment) AND aggressive AND (thyroid carcinomas OR thyroid neoplasms). The combination of these keywords was used to search the electronic databases. The included studies must have recent advances in pharmacological therapies for advanced TC, been published in the last 7 years and be written in English. Relevant studies mentioned in articles included in our search were also considered (even if older than 7 years only because of their relevance in a purpose of giving a context).

We excluded studies published more than 7 years ago, those published in a language other than English, case reports and articles focusing exclusively PDTC, ATC or MTC.

After performing the initial literature searches, each study title and abstract was screened for eligibility. Full text of all potentially relevant studies was subsequently retrieved and further examined for eligibility. 59 articles were included in this review.

\section{Conventional cytotoxic chemotherapy}

For multiple and progressive metastatic lesions with a high-tumor burden, some cytotoxic therapies have been applied [14]. Historically, adriamycin alone or in combination has been the most-common cytotoxic drug used. A retrospective study from 2008 with adriamycin alone showed only a modest efficacy with one patient achieving a partial response out of 22 patients [15]. Another retrospective study from 2013 with adriamycin plus cisplatin or cyclophosphamide showed a response rate of $20 \%$ [16].

Other studies with nonadriamycin-based regimens have shown more consistent benefit. One from 2002 using carboplatin plus epirubicin showed a response rate of $43 \%$ in 14 RAIRTC patients [17] and another from 2012 with the gemcitabine plus oxaliplatin regimen showed an overall response of $57 \%$. Most patients had pulmonary and lymph node metastases [14,18]. These cytotoxic protocols can be useful and need further investigation. A Phase II study evaluating the efficacy and safety of gemcitabine plus oxaliplatin in advanced refractory TC is now enrolling patients [19].

\section{Molecular-target therapy}

Rationale of molecular-target therapy

In recent years, advances in the genomic knowledge of DTC have opened new therapeutic opportunities.

The MAPK pathway plays a central role in PTC, which is stimulated by activating, and mutually exclusive, mutations in BRAF (around 60\%), RAS family genes (13\%) and RET-PTC fusion oncoproteins [20,21]. MAPK activation also promotes expression of other oncoproteins, important for tumor microenvironment [21]. In FTC, $R A S$ and PPAR $\gamma$ rearrangements are the most-common mutations [21].

Another major signaling pathway is PI3K-AKT-mTOR, which is an important regulator of apoptosis, proliferation and cell migration. Activation of this pathway occurs in FTC, PDTC and ATC and can be the result of gain-of-function mutations in PI3K catalytic, alpha polypeptide (PI3KCA) and AKT1 or inactivating mutations in PTEN. Additionally, RAS mutations can also stimulate the PI3K-AKT-mTOR pathway, contributing to disease progression in PDTC and ATC, in which cumulative mutations are more frequent $[21,22]$.

Other mutations observed in PDTC and ATC occur in TP53, ALK, EGFR, TERT and EIF1AX-RAS, the last frequently associated with $R A S$ mutations (Figure 1) [22].

Angiogenesis plays a critical role in the proliferation of DTC since peritumoral angiogenesis and microvascular density are increased in aggressive tumors. Higher VEGF and VEGFR, PDGF, and FGF and FGFR tissue levels have also been associated with aggressive behavior [21,23-25].

The expanding knowledge of molecular targets, described in detail in Figure 1, may be clinically relevant. Table 1 exhibits the molecular targets of different clinical relevant inhibitors [26-32]. 


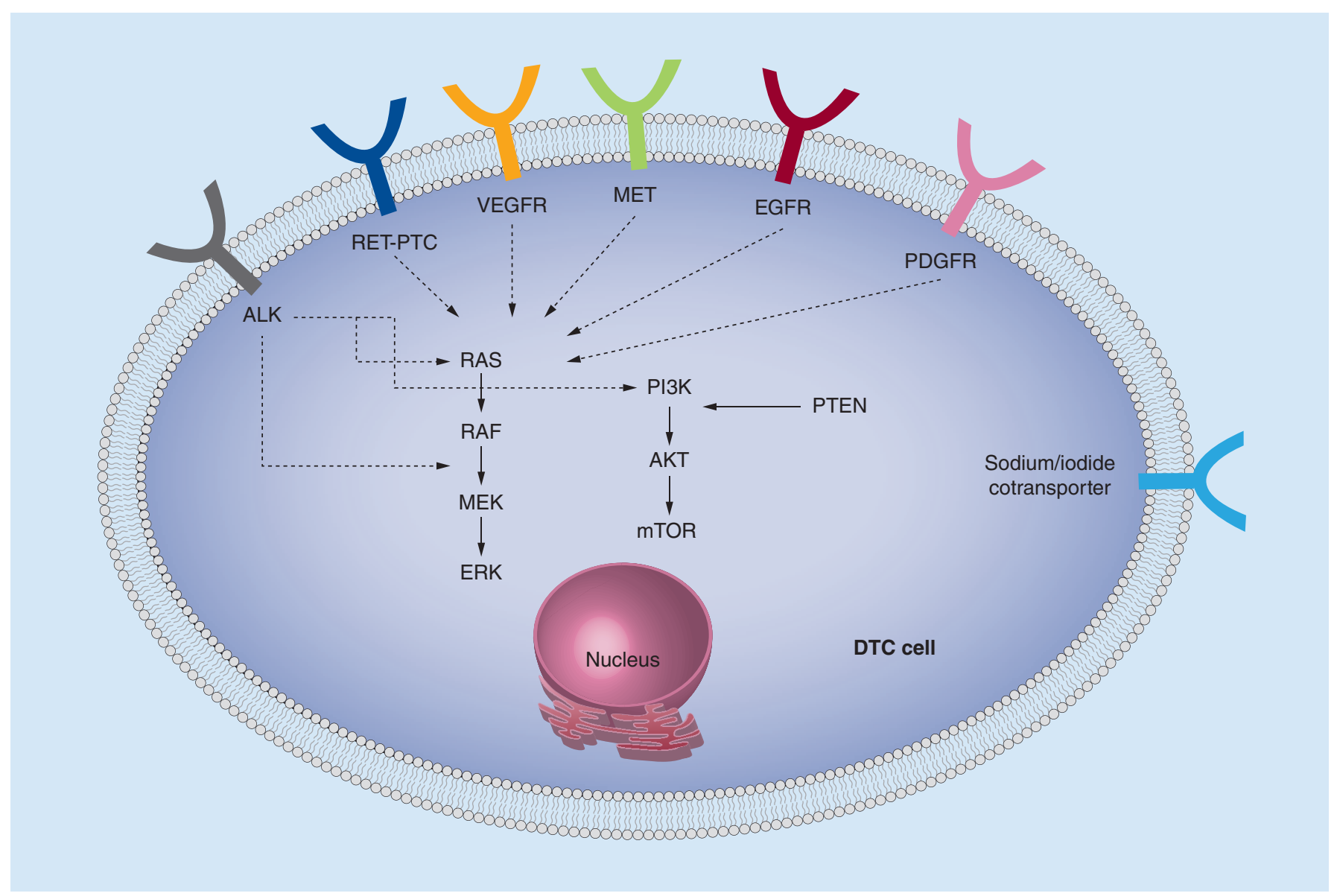

Figure 1. Schematic representation of the major signaling pathways associated with differentiated thyroid cancer. DTC: Differentiated thyroid cancer; PTC: Papillary thyroid carcinoma.

\section{Efficacy of tyrosine kinase inhibitors in TC}

Tyrosine kinase inhibitors (TKIs) are increasingly being used in advanced and RAIRTC, for which the therapeutic options have been limited for decades.

Two TKIs are currently approved for advanced TC, others being used off-label based on the results of Phase II trials [27,29] and some are being studied in Phase I, II or III [27,33-34].

A large systematic review and meta-analysis involving 22 studies and 1435 patients (mostly Phase II trials evaluating response in DTC but also in MTC patients), comprehending ten different TKIs, showed an objective response in $16 \%$ of DTC patients. Clinical benefit was observed in $51 \%$ of patients. Gefitinib and imatinib induced no objective responses, and pazopanib showed the highest objective response rate in DTC patients (49\%). Sorafenib was the most studied TKI showing a clinical benefit in 53\% of DTC patients. Lenvatinib studies were not available in this meta-analysis [35].

The DECISION trial was a multicentric, randomized, double-blind, placebo-controlled, Phase III study that investigated sorafenib in patients with locally advanced/metastatic RAIRTC showing recent progression. A total of 417 patients were randomized to sorafenib or placebo (1:1). Approximately 10\% of patients had PDTC and 96\% of patients had distant metastases. Less than 5\% of patients had previously received systemic anticancer therapy [36].

Sorafenib significantly improved progression-free survival (PFS) compared with placebo (median: 10.8 vs 5.8 months, respectively). There was no significant difference in overall survival (OS). Response rates (all partial responses) significantly increased in the sorafenib group compared with placebo (12.2 vs $0.5 \%)$. Treatment benefit occurred mostly in patients with lung metastases. Bone metastases showed only modest responses. Biochemical responses were also observed in the sorafenib arm, with initial decreases in serum thyroglobulin levels in most patients. 


\begin{tabular}{|c|c|c|c|c|c|c|c|}
\hline Drug & VEGFR & c-KIT & RET & PDGFR & FGFR & EGFR & Others \\
\hline Sorafenib & $\mathrm{x}$ & $\mathrm{x}$ & $\mathrm{x}$ & $X(\beta)$ & & & RAF, FLT3 \\
\hline Lenvatinib & $\mathrm{x}$ & $\mathrm{x}$ & $\mathrm{x}$ & $X(\alpha)$ & $\mathrm{x}$ & & $\begin{array}{l}\text { KIF5B-RET, CCDC6-RET, } \\
\text { NcoA4-RET rearrangement }\end{array}$ \\
\hline Sunitinib & $\mathrm{x}$ & $\mathrm{x}$ & $\mathrm{x}$ & $\mathrm{x}$ & & & FLT3 \\
\hline Gefitinib & & & & & & $\mathrm{x}$ & \\
\hline Imatinib & & $\mathrm{x}$ & & $\mathrm{x}$ & & & Bcr-Abl \\
\hline Pazopanib & $\mathrm{x}$ & $\mathrm{x}$ & & $\mathrm{x}$ & & & \\
\hline Vandetanib & $\mathrm{x}$ & $\mathrm{x}$ & $\mathrm{x}$ & & & & \\
\hline Crizotinib & & & & & & & MET, ALK, ROS1 \\
\hline Lapatinib & & & & & & $\mathrm{x}$ & HER2/3 \\
\hline Cabozantinib & $\mathrm{x}$ & $\mathrm{x}$ & $\mathrm{x}$ & & & & MET, KIF5B-RET rearrangement \\
\hline Nintendanib & $\mathrm{x}$ & & & $\mathrm{x}$ & $\mathrm{x}$ & & \\
\hline Tipifarnib & & & & & & & HRAS \\
\hline Motesanib & $\mathrm{x}$ & $\mathrm{x}$ & $\mathrm{x}$ & $\mathrm{x}$ & & & \\
\hline Axitinib & $\mathrm{x}$ & $\mathrm{x}$ & & $\mathrm{x}$ & & & \\
\hline Vemurafenib & & & & & & & BRAF \\
\hline Dabrafenib & & & & & & & BRAF \\
\hline Selumetinib & & & & & & & MEK1/2, RAS \\
\hline Trametinib & & & & & & & MEK1/2 \\
\hline Everolimus & & & & & & & mTOR, PI3K \\
\hline Temsirolimus & & & & & & & mTOR, PI3K \\
\hline
\end{tabular}

The SELECT trial was also a Phase III, double-blind study involving patients with progressive RAIRTC, that randomly assigned 261 patients to receive lenvatinib and 131 patients to placebo. Both groups included patients with PDTC, representing more than $10 \%$ of the cases. Bone or lung metastases were present in nearly 40 and $90 \%$, respectively, and almost $25 \%$ of patients had previously received therapy with TKI [37].

The median PFS was significantly increased in the treatment group: 18.3 months in the lenvatinib group versus 3.6 months with placebo. The response rate was significantly greater in the lenvatinib group $(64.8 \%$, including four complete responses) against $1.5 \%$ with placebo. Progressive disease occurred in $6.9 \%$ of the patients in the lenvatinib group as compared with $39.7 \%$ in the placebo group. The difference in OS between groups was not significant.

A subanalysis of the SELECT trial showed a significant benefit in OS in older patients, but this group also had an increased frequency of severe adverse events (AEs) [38].

A PFS benefit associated with lenvatinib and sorafenib was observed in all prespecified subgroups, and within any biomarker/genetic subgroups [36,37].

The benefit of TKI in OS is yet to be proven, will require more extensive trials and may be difficult to prove in crossover-designed trials.

\section{AEs \& toxicities}

In the DECISION trial, AEs and dose reductions/interruptions due to treatment-related AEs were extremely frequent. The most-common AEs with sorafenib were hand-foot skin reaction, diarrhea, alopecia, rash/desquamation, fatigue, weight loss and hypertension [36].

In the SELECT trial, AEs of any grade occurred in more than $40 \%$ of patients in the lenvatinib group, causing drug discontinuation in 14.2 and $2.3 \%$ of patients in the active treatment and placebo groups, respectively. Six of the 20 deaths that occurred during the treatment period were considered to be drug related. The main AEs with lenvatinib were hypertension, proteinuria, arterial and venous thromboembolic events, renal and hepatic failure, gastrointestinal fistula, QT prolongation and posterior reversible encephalopathy syndrome [37].

In the meta-analysis of Klein Hesselink et al. [35], AEs and dose reductions or discontinuations due to treatmentrelated AEs were also very common. Sorafenib and cabozantinib were associated with the highest percentage of 
Table 2. Most-common adverse events with tyrosine kinase inhibitors and its management.

\begin{tabular}{|c|c|c|}
\hline Toxicity & Comment & Management \\
\hline $\begin{array}{l}\text { General symptoms: including fatigue and weight } \\
\text { loss }\end{array}$ & May be due to AMPK inhibition & $\begin{array}{l}\text { Appropriate physical effort adjustment and } \\
\text { nutritional support }\end{array}$ \\
\hline $\begin{array}{l}\text { - Cardiovascular toxicity: HBP/worsening of } \\
\text { pre-existing HBP ischemic events, heart failure, QT } \\
\text { prolongation } \\
\text { - Lesions encasing important blood vessels carry } \\
\text { increased hemorrhagic risk }\end{array}$ & $\begin{array}{l}\text { - Cardiovascular toxicity is mainly driven by VEGFR } \\
\text { inhibition } \\
\text { - Appropriate cardiovascular evaluation before } \\
\text { TKI initiation, including arterial pressure, } \\
\text { electrocardiogram and echocardiogram in } \\
\text { selected patient }\end{array}$ & $\begin{array}{l}\text { - Aggressive treatment of HBP (dihydropyridines } \\
\text { may be more effective) } \\
\text { - Hold therapy if QTC }>480 \mathrm{~ms} \\
\text { - Consider delay TKI if recent major cardiovascular } \\
\text { event } \\
\text { - Avoid TKI in TC lesions encasing important } \\
\text { blood vessels }\end{array}$ \\
\hline $\begin{array}{l}\text { Endocrine effects: increased requirements in } \\
\text { levothyroxine (hypothyroidism), calcium and D } \\
\text { vitamin ( } 25 \text {-hydroxyvitamin D) }\end{array}$ & & $\begin{array}{l}\text { - Frequent monitoring of TSH, thyroid hormones } \\
\text { and calcium } \\
\text { - Appropriate therapy adjustments }\end{array}$ \\
\hline $\begin{array}{l}\text { Cutaneous effects: HFSR, alopecia, rash, acne, } \\
\text { pruritus, dry skin, paronychia, mucositis, yellow } \\
\text { skin discoloration }\end{array}$ & $\begin{array}{l}\text { - Most cutaneous AEs result from inhibition of } \\
\text { EGFR activity } \\
\text { - Yellow skin discoloration is potentially a result } \\
\text { of the orange excipient used in sunitinib tablets, a } \\
\text { direct effect of the drug or its metabolites }\end{array}$ & $\begin{array}{l}\text { - Avoidance of sun exposure or use SPF } 30 \\
\text { UVA/UVB nonocclusive sunscreen } \\
\text { - Avoidance of extreme temperatures, physical } \\
\text { trauma-like friction and potential irritating agents } \\
\text { - Use of ointments, emollients, soap substitutes, } \\
\text { urea cream, topical corticosteroids, antihistamines } \\
\text { and clindamycin lotion for skin problems } \\
\text { - Mouth wash with saline or bicarbonate } \\
\text { solutions, antifungals/antibiotics as needed for } \\
\text { mucositis }\end{array}$ \\
\hline $\begin{array}{l}\text { Gastrointestinal effects: diarrhea, } \\
\text { nausea/vomiting, aerodigestive fistula, toxic, } \\
\text { hepatitis, pancreatitis }\end{array}$ & $\begin{array}{l}\text { - Diarrhea results from EGFR inhibition } \\
\text { - Recent digestive surgery, diverticulitis, } \\
\text { inflammatory bowel disease or active ulcer } \\
\text { increases risk of bleeding or perforation }\end{array}$ & $\begin{array}{l}\text { - Ingestion of isotonic fluids, loperamide and } \\
\text { codeine for diarrhea } \\
\text { - Frequent monitoring of hepatic blood tests and } \\
\text { lipase }\end{array}$ \\
\hline Hematological toxicities: bone marrow aplasia & & Serial complete blood count \\
\hline $\begin{array}{l}\text { Miscellaneous effects: proteinuria, delayed } \\
\text { scarring }\end{array}$ & $\begin{array}{l}\text { - Proteinuria is frequent with lenvatinib } \\
\text { - Lenvatinib causes inhibition of FGFR and may } \\
\text { significantly delay/impair tissue repair }\end{array}$ & $\begin{array}{l}\text { TKI should be withheld during radiotherapy } \\
\text { because of increased risk of local tissue } \\
\text { necrosis, major surgery and immediate } \\
\text { postoperative period, to allow tissue repair }\end{array}$ \\
\hline
\end{tabular}

dose reductions or discontinuation (70 and 77\%, respectively) due to AEs. The most frequent AEs were hand-foot skin reaction, diarrhea and nausea/vomiting, which could be quite disabling [35].

TKIs can induce multiple AEs that require close monitoring and frequently dosage reductions or therapy suspension, depending on severity. Patients should be instructed about potential AEs and protective measures that can prevent or minimize their severity. The assessment of AEs should comprehend severity scales like the common terminology criteria for AEs since this may help to assist in treatment reductions/withdrawals [39]. Table 2 describes the most common AEs and strategies to manage them $[11,40-45]$.

\section{Timing to stop or switch TKI}

Development of severe/intolerable AEs is an obvious reason to stop TKI. Progressive disease under TKI therapy (using the response evaluation criteria in solid tumors criteria) is another logical reason to stop this medication, but we need to bear in mind that there are only a few options for advanced DTC and that progression of disease may accelerate after stopping these agents. There is really no limit on the duration of treatment and some patients will experience years of drug exposure. Whether there is a real benefit of switching from one TKI to another is not clear, nevertheless, this strategy was evaluated in the SELECT trial with favorable results of lenvatinib as a second-line TKI [37]. A retrospective study also analyzed the use of a second-line TKI in advanced TC after first-line TKI failure. TC patients treated with second-line therapy in this study had a stable disease as best response. There were no significant differences in median PFS comparing first- and second-line TKI treatment [45].

\section{Conclusion}

We are living in an era of rapid expansion in available therapies for advanced TC. TKIs can provide significant increases in PFS but carry the risk of significant toxicity. Emerging classes in experimental stages will potentially optimize the treatment of TC patients. Redifferentiation of tumors holds great promise for the future. Molecular- 
target therapy following a more individualized approach is a matter of special interest. Important steps to achieve efficient, well-tolerated drugs are underway, but significant work still needs to be done.

\section{Future perspective}

There are 48 Phase II-IV clinical trials enrolled at clinicaltrials.gov and 22 Phase II-IV at EU Clinical Trials Register. Details about the name of the drugs, phase of the study, primary outcomes, patients enrolled, time of start and estimated time of completion may be seen in Tables $3 \& 4$ [27,46-47].

\section{BRAF inhibitors}

Vemurafenib and dabrafenib are small inhibitors highly selective to the BRAF-V600E mutations, which are being studied in Phase II trials [27-30].

Vemurafenib was efficient in some BRAFV600E-positive advanced RAIRTC patients (partial responses of 35$38.5 \%$ in naive patients and $26-29 \%$ in those previously exposed to a VEGFR inhibitor) [29-30,48-49]. Severe AEs were noted in 65 and $68 \%$ of the two groups, respectively, [29,48] with $22 \%$ developing cutaneous squamous cell carcinoma $[28,30]$.

Dabrafenib revealed positive results in studies with BRAFV600E-mutated PTC patients, achieving new RAI uptake and partial and prolonged responses. Dabrafenib was well tolerated, with no patient requiring dose reduction even in long-term treatment $[28-29,50-51]$.

Combination therapy of dabrafenib with lapatinib showed favorable results in patients refractory to other treatments. Dabrafenib associated with trametinib revealed promising results in recurrent TC $[27,28]$. The most common AEs with these drugs are dermatological, gastrointestinal and constitutional [28,30].

\section{MEK inhibitors}

Selumetinib proved to be capable of reintroducing RAI uptake into RAIRTC [29,52]. Despite a disappointing antitumor effect in one study, it was responsible for increasing RAI uptake in $60 \%$ of the cases in a mixed group of PTC and PDTC [29]. There seems to be a tumor genotype correlation with changes in RAI avidity, being the NRAS-mutant tumors those which benefit the most [29,53-54]. At the present time, monotherapy with selumetinib has achieved only modest success $[28,51]$.

Trametinib is under evaluation in a Phase II study to test tumoral iodine reincorporation in advanced TC [27].

\section{mTOR inhibitors}

mTOR upregulation has been associated with TC [55]. Two mTOR inhibitors are being studied, everolimus and temsirolimus. The clinical results with everolimus monotherapy were disappointing, probably due to an early adaptive resistance. This could be related to a feedback loop between mTOR pathway and RAS/MAPK/ERK signaling, resulting in activation of an alternative prosurvival pathway upon mTOR inhibition. Therefore, the use of everolimus in combined therapies is now being studied [28-29,49,55].

The association of sorafenib plus everolimus was already evaluated in a Phase II trial of patients who progressed on sorafenib, showing promising results. This combination is already being used as second-line therapy in centers where lenvatinib is not available $[28,49]$.

\section{ALK inhibitors}

$A L K$ gene fusions, involving mainly the striatin gene (SRTN), result in increased MAPK activity and have been reported in patients with RAIRTC, specially PDTC and ATC. Crizotinib, a specific inhibitor of $A L K$ translocation, showed promising results in $A L K$-mutated TC cell cultures and a clinical trial is currently underway [56,57].

\section{Immunotherapy}

Immunotherapy has emerged as a promising therapy since it already proved to be effective in other aggressive tumors. There is evidence of some immunological differences in advanced TC compared with normal thyroidal tissue/nonaggressive TC, such as an overexpression of mast cells, reduced peripheral natural killer cell cytotoxicity, preference by M2 phenotype in tumor-associated macrophages, inefficient dendritic cell maturation, higher concentration of myeloid-derived suppressor cells, T-cell dysfunction and overexpression of regulatory $\mathrm{T}$ cells $[58,59]$. All of this may lead to an immune evasion by cancer cells and progression of the disease [58,59]. There are preclinical and clinical trials at the moment studying therapies targeting tumor-associated macrophages, tumor antigens, $\mathrm{T}$ 
Table 3. Details about Phase II-IV clinical trials enrolled at clinicaltrials.com which include advanced differentiated thyroid cancer.

\begin{tabular}{|c|c|c|c|c|c|c|}
\hline Drug & Identifier & $\begin{array}{l}\text { Phase of } \\
\text { study }\end{array}$ & Primary outcomes & Patients & Time of start & $\begin{array}{l}\text { Estimated time } \\
\text { of completion }\end{array}$ \\
\hline Anlotinib & NCT02586337 & II and III & PFS & RAIRTC & July 2015 & December 2017 \\
\hline Apatinib & NCT03048877 & III & PFS & $\begin{array}{l}\text { Locally advanced or metastatic RAIRTC showing } \\
\text { disease progression within } 12 \text { months before } \\
\text { inclusion }\end{array}$ & December 2016 & December 2019 \\
\hline Lenvatinib & NCT02966093 & III & PFS & $\begin{array}{l}\text { RAIRTC not eligible for possible curative surgery } \\
\text { with evidence of progression within } 12 \text { months } \\
\text { after initiation of study }\end{array}$ & February 2017 & April 2020 \\
\hline Alectinib & NCT03131206 & II & $\begin{array}{l}\text { Maximum tolerated dose; } \\
\text { ORR }\end{array}$ & $\begin{array}{l}\text { Metastatic RAIRTC that carries an RET } \\
\text { rearrangement or an activating RET mutation } \\
\text { with disease progression after at least one prior } \\
\text { line of systemic therapy }\end{array}$ & June 2017 & May 2020 \\
\hline Apatinib & NCT02731352 & II & $\begin{array}{l}\text { Disease control rate and } \\
\text { ORR }\end{array}$ & $\begin{array}{l}\text { Locally advanced or metastatic RAIRTC showing } \\
\text { disease progression within } 14 \text { months before } \\
\text { inclusion }\end{array}$ & February 2016 & Not mentioned \\
\hline Apatinib & NCT03167385 & II & Disease control rate & $\begin{array}{l}\text { Locally advanced or metastatic DTC, which cannot } \\
\text { be resected completely, is not suitable or is } \\
\text { refractory to RAI with imagiological progression } \\
\text { in the last } 18 \text { months }\end{array}$ & March 2017 & December 2020 \\
\hline Apatinib & NCT03199677 & II & ORR & RAIRTC & July 2017 & June 2018 \\
\hline Buparlisib & NCT01830504 & II & PFS & $\begin{array}{l}\text { Metastatic or locally invasive RAIRTC or PDTC with } \\
\text { evidence of progression within the last } 12 \text { months }\end{array}$ & April 2013 & January 2017 \\
\hline Cabozantinib & NCT02041260 & II & Number of AEs & $\begin{array}{l}\text { Metastatic/unresectable RAIRTC with evidence of } \\
\text { progression within } 14 \text { months before starting } \\
\text { treatment }\end{array}$ & January 2014 & January 2018 \\
\hline Cabozantinib & NCT01811212 & II & ORR & $\begin{array}{l}\text { RAIRTC that has progressed with at least two } \\
\text { VEGFR-targeted therapy }\end{array}$ & May 2013 & Not mentioned \\
\hline CUDC-907 & NCT03002623 & II & $\begin{array}{l}\text { Changes in tumor size and } \\
\text { metastases }\end{array}$ & $\begin{array}{l}\text { TC that is refractory to or relapsed after standard } \\
\text { treatment }\end{array}$ & December 2016 & March 2025 \\
\hline $\begin{array}{l}\text { Cyclophosphamide } \\
\text { plus sirolimus }\end{array}$ & NCT03099356 & II & $\begin{array}{l}\text { Percentage of patients } \\
\text { that respond to treatment }\end{array}$ & $\begin{array}{l}\text { RAIRTC not amenable to curative treatment or } \\
\text { who refuse standard treatment }\end{array}$ & April 2017 & May 2023 \\
\hline $\begin{array}{l}\text { Dabrafenib, } \\
\text { dabrafenib plus } \\
\text { trametinib }\end{array}$ & NCT01723202 & II & ORR & $\begin{array}{l}\text { RAIRTC or PDTC BRAF mutated with evidence of } \\
\text { progression within } 13 \text { months before starting the } \\
\text { study }\end{array}$ & November 2012 & December 2019 \\
\hline Donafenib & NCT02870569 & II & OS & $\begin{array}{l}\text { Advanced or metastatic RAIRTC with evidence of } \\
\text { disease progression within } 14 \text { months prior to } \\
\text { initiation of study }\end{array}$ & September 2016 & December 2019 \\
\hline Entrectinib & NCT02568267 & II & ORR & $\begin{array}{l}\text { Locally advanced or metastatic TC that harbors an } \\
\text { NTRK1/2/3, ROS1 or ALK gene rearrangement }\end{array}$ & October 2015 & October 2018 \\
\hline $\begin{array}{l}\text { Everolimus plus } \\
\text { sorafenib }\end{array}$ & NCT01263951 & II & $\begin{array}{l}\text { PFS, ORR and stable } \\
\text { disease }\end{array}$ & $\begin{array}{l}\text { Advanced DTC for whom standard curative or } \\
\text { palliative measures do not exist or are no longer } \\
\text { effective and who have progressed on sorafenib } \\
\text { alone }\end{array}$ & November 2010 & Not mentioned \\
\hline Everolimus & NCT00936858 & II & PFS & $\begin{array}{l}\text { Advanced or metastatic DTC with evidence of } \\
\text { progression by modified RECIST within } 6 \text { months } \\
\text { before study day } 1 \text { and not amenable to or } \\
\text { refractory to surgical resection, RT, RAI or other } \\
\text { local therapies }\end{array}$ & July 2009 & December 2017 \\
\hline $\begin{array}{l}\text { Everolimus, } \\
\text { pasireotide, } \\
\text { everolimus plus } \\
\text { pasireotide }\end{array}$ & NCT01270321 & II & ORR & $\begin{array}{l}\text { RAIRTC with evidence of biochemical or } \\
\text { radiological progression within the last } 12 \text { months } \\
\text { prior to enrollment }\end{array}$ & November 2010 & June 2018 \\
\hline $\begin{array}{l}\text { Everolimus plus } \\
\text { sorafenib }\end{array}$ & NCT01141309 & II & ORR & $\begin{array}{l}\text { Progressive surgically inoperable and/or } \\
\text { recurrent/metastatic TC with at least one } \\
\text { FDG-avid lesion that has not been removed } \\
\text { surgically or radiated }\end{array}$ & June 2010 & June 2018 \\
\hline \multicolumn{7}{|c|}{$\begin{array}{l}\text { 99mTc HMDP: Technetium-99 hydroxymethylene diphosphonate; AE: Adverse event; CT: Computed tomography; DTC: Differentiated thyroid cancer; EAY131: National Cancer Institute } \\
\text { (NCI)-Molecular Analysis for Therapy Choice (MATCH); FDG: 8F-fluorodeoxyglucose; FTC: Follicular thyroid cancer; I-124: lodine-124; IMRT: Intensity-modulated radiation therapy; MTC: } \\
\text { Medullary thyroid cancer; NCI-MATCH: Molecularly matched therapy and have no further molecularly matched treatment recommendations per EAY131; ORR: Overall response rate; } \\
\text { OS: Overall survival; PERCIST: Positron emission tomography response criteria in solid tumor; PDTC: Poorly differentiated thyroid cancer; PFS: Progression-free survival; RAI: Radioiodine; } \\
\text { RAIRTC: Radioiodine refractory thyroid cancer; RECIST: Response evaluation criteria in solid tumor; RT: External beam radiation; TA: Total activity; TC: Thyroid cancer. }\end{array}$} \\
\hline
\end{tabular}


Table 3. Details about Phase II-IV clinical trials enrolled at clinicaltrials.com which include advanced differentiated thyroid cancer (cont.).

\begin{tabular}{|c|c|c|c|c|c|c|}
\hline Drug & Identifier & $\begin{array}{l}\text { Phase of } \\
\text { study }\end{array}$ & Primary outcomes & Patients & Time of start & $\begin{array}{l}\text { Estimated time } \\
\text { of completion }\end{array}$ \\
\hline $\begin{array}{l}\text { Gemcitabine plus } \\
\text { oxaliplatin }\end{array}$ & NCT02472080 & II & $\begin{array}{l}\text { ORR (complete and partial } \\
\text { responses) measured by CT } \\
\text { scan according to RECIST } \\
\text { criteria }\end{array}$ & $\begin{array}{l}\text { Metastatic or unresectable RAIRTC or PDTC with } \\
\text { radiologic evidence of clinically relevant disease } \\
\text { progression }\end{array}$ & April 2016 & July 2018 \\
\hline $\begin{array}{l}\text { IMRT plus } \\
\text { doxorubicin }\end{array}$ & NCT01882816 & II & Rates of local/regional PFS & $\begin{array}{l}\text { Nonanaplastic non-MTC that is either grossly } \\
\text { recurrent after surgery or unresectable with or } \\
\text { without metastatic disease }\end{array}$ & June 2013 & June 2018 \\
\hline $\begin{array}{l}\text { Ipilimumab plus } \\
\text { nivolumab }\end{array}$ & NCT02834013 & II & ORR & $\begin{array}{l}\text { Rare cancer that does not have a match to a } \\
\text { molecularly guided therapy on EAY } 131 \text { protocol } \\
\text { or who progressed on NCI-MATCH and there are } \\
\text { no other approved/standard therapies available } \\
\text { that have shown to prolong OS }\end{array}$ & January 2017 & Not mentioned \\
\hline Larotrectinib & NCT02576431 & II & ORR & $\begin{array}{l}\text { Locally advanced or metastatic TC with an } \\
\text { NTRK } 1 / 2 / 3 \text { gene fusion that have received or are } \\
\text { unlikely to tolerate/benefit standard therapy }\end{array}$ & October 2015 & December 2019 \\
\hline Lenalidomida & NCT00287287 & II & Tumor response & $\begin{array}{l}\text { Unresectable, distantly metastatic RAIRTC with } \\
\text { imagiological progression within the last } \\
12 \text { months }\end{array}$ & February 2006 & December 2017 \\
\hline Lenvatinib & NCT02702388 & II & $\begin{array}{l}\text { Evaluate whether an oral } \\
\text { starting dose of 18-mg } \\
\text { daily will provide } \\
\text { comparable efficacy to a } \\
24 \text { mg starting dose, but a } \\
\text { better safety profile }\end{array}$ & RAIRTC with disease progression within 12 months & March 2016 & October 2020 \\
\hline $\begin{array}{l}\text { Lenvatinib plus } \\
\text { everolimus }\end{array}$ & NCT03139747 & II & $\begin{array}{l}\text { Number of subjects with } \\
\text { PFS }\end{array}$ & $\begin{array}{l}\text { Metastatic or unresectable DTC for which } \\
\text { standard curative or palliative measures do not } \\
\text { exist or are no longer effective that have } \\
\text { progressed on lenvatinib alone (but with previous } \\
\text { stable disease for at least } 4 \text { months) }\end{array}$ & April 2017 & April 2020 \\
\hline Nintendanib & NCT01788982 & II & PFS & $\begin{array}{l}\text { Locally advanced or metastatic DTC deemed } \\
\text { incurable by surgery, radiotherapy and/or RAI }\end{array}$ & May 2014 & January 2018 \\
\hline $\begin{array}{l}\text { Nivolumab plus } \\
\text { ipilimumab }\end{array}$ & NCT03246958 & II & $\begin{array}{l}\text { Radiographic response } \\
\text { rate }\end{array}$ & $\begin{array}{l}\text { Metastatic RAIRTC with progression within } \\
13 \text { months prior to study registration }\end{array}$ & September 2017 & March 2025 \\
\hline Pazopanib & NCT01813136 & II & $\begin{array}{l}\text { Time to treatment failure } \\
\text { comparing continuous } \\
\text { with intermittent schedule }\end{array}$ & $\begin{array}{l}\text { RAIRTC or PDTC with imagiological evidence of } \\
\text { progression within the last } 12 \text { months }\end{array}$ & March 2013 & June 2018 \\
\hline Pazopanib & NCT00625846 & II & $\begin{array}{l}\text { Confirmed tumor } \\
\text { response; proportion of } \\
\text { patients who have } \\
\text { achieved an objective } \\
\text { response }\end{array}$ & $\begin{array}{l}\text { Advanced or metastatic RAIRTC, MTC or ATC with } \\
\text { evidence of disease progression within } 6 \text { months } \\
\text { before starting treatment }\end{array}$ & February 2008 & Not mentioned \\
\hline $\begin{array}{l}\text { Pembrolizumab } \\
\text { and lenvatinib }\end{array}$ & NCT02973997 & II & Confirmed response rate & $\begin{array}{l}\text { Locally recurrent and unresectable and/or distant } \\
\text { metastatic RAIRTC with evidence of progression } \\
\text { within } 14 \text { months or progression with lenvatinib } \\
\text { alone within } 30 \text { days before starting the study }\end{array}$ & April 2017 & Not mentioned \\
\hline Pembrolizumab & NCT02628067 & II & ORR & $\begin{array}{l}\text { Progressive TC intolerant to therapies known to } \\
\text { provide clinical benefit }\end{array}$ & December 2015 & August 2023 \\
\hline Radium 223 & NCT02390934 & II & $\begin{array}{l}\text { Metabolic response } \\
\text { according to PERCIST } \\
\text { criteria }\end{array}$ & $\begin{array}{l}\text { RAIRTC with at least one bone metastasis } \\
\text { observed on CT/MRI, with uptake on PET-FDG and } \\
\text { 99mTc-HMDP bone scintigraphy or FNa PET/CT }\end{array}$ & October 2014 & March 2018 \\
\hline $\begin{array}{l}\text { Selumetinib plus } \\
\text { RAI }\end{array}$ & NCT02393690 & II & Response rate & $\begin{array}{l}\text { Recurrent and/or metastatic TC with a RAl-avid } \\
\text { lesion on an RAI scan performed within } 24 \text { months } \\
\text { before therapy }\end{array}$ & May 2015 & August 2020 \\
\hline $\begin{array}{l}\text { Sorafenib, } \\
\text { sorafenib plus } \\
\text { everolimus }\end{array}$ & NCT02143726 & II & PFS & $\begin{array}{l}\text { Metastatic or locally advanced unresectable } \\
\text { refractory Hurthle cell TC with evidence of } \\
\text { progression on the } 14 \text { months before study whom } \\
\text { are naive for sorafenib and mTOR inhibitor }\end{array}$ & October 2014 & Not mentioned \\
\hline \multicolumn{7}{|c|}{$\begin{array}{l}\text { 99mTC HMDP: Technetium-99 hydroxymethylene diphosphonate; AE: Adverse event; CT: Computed tomography; DTC: Differentiated thyroid cancer; EAY131: National Cancer Institute } \\
\text { (NCI)-Molecular Analysis for Therapy Choice (MATCH); FDG: 8F-fluorodeoxyglucose; FTC: Follicular thyroid cancer; I-124: Iodine-124; IMRT: Intensity-modulated radiation therapy; MTC: } \\
\text { Medullary thyroid cancer; NCI-MATCH: Molecularly matched therapy and have no further molecularly matched treatment recommendations per EAY131; ORR: Overall response rate; } \\
\text { OS: Overall survival; PERCIST: Positron emission tomography response criteria in solid tumor; PDTC: Poorly differentiated thyroid cancer; PFS: Progression-free survival; RAI: Radioiodine; } \\
\text { RAIRTC: Radioiodine refractory thyroid cancer; RECIST: Response evaluation criteria in solid tumor; RT: External beam radiation; TA: Total activity; TC: Thyroid cancer. }\end{array}$} \\
\hline
\end{tabular}


Table 3. Details about Phase II-IV clinical trials enrolled at clinicaltrials.com which include advanced differentiated thyroid cancer (cont.).

\begin{tabular}{|c|c|c|c|c|c|c|}
\hline Drug & Identifier & $\begin{array}{l}\text { Phase of } \\
\text { study }\end{array}$ & Primary outcomes & Patients & Time of start & $\begin{array}{l}\text { Estimated time } \\
\text { of completion }\end{array}$ \\
\hline Sorafenib & NCT02084732 & II & $\begin{array}{l}\text { Describe the clinical } \\
\text { activity and safety profile }\end{array}$ & $\begin{array}{l}\text { Metastatic or unresectable DTC for whom } \\
\text { conventional curative or palliative therapeutic } \\
\text { options do not exist or are not effective }\end{array}$ & October 2013 & June 2018 \\
\hline Sulfatinib & NCT02614495 & II & ORR & $\begin{array}{l}\text { Locally advanced and/or metastatic RAIRTC or } \\
\text { MTC with evidence of disease progression within } \\
12 \text { months before starting therapy }\end{array}$ & February 2016 & December 2018 \\
\hline $\begin{array}{l}\text { Temsirolimus plus } \\
\text { sorafenib }\end{array}$ & NCT01025453 & II & ORR & $\begin{array}{l}\text { Progressive surgically inoperable and/or } \\
\text { recurrent/metastatic RAIRTC with at least one } \\
\text { FDG-avid lesion that has not been removed } \\
\text { surgically or radiated }\end{array}$ & December 2009 & December 2017 \\
\hline $\begin{array}{l}\text { Trametinib plus } \\
\text { RAl, trametinib } \\
\text { plus dabrafenib } \\
\text { plus RAl }\end{array}$ & NCT03244956 & II & ORR & $\begin{array}{l}\text { RAIRTC (TA } \leq 300 \mathrm{mCi} \text { ) positive for RAS mutation } \\
\text { with progression of disease within } 18 \text { months } \\
\text { prior initiation of therapy and absence of } \\
\text { metastatic lesion }>30 \mathrm{~mm}\end{array}$ & July 2017 & August 2022 \\
\hline Trametinib & NCT02152995 & II & $\begin{array}{l}\text { lodine incorporation in TC } \\
\text { metastases to a predicted } \\
\text { lesional absorbed } \\
\text { radiation dose } \geq 2000 \text { cGy } \\
\text { with the administration of } \\
\leq 300 \mathrm{mCi} \text { RAI; ORR; PFS; } \\
\text { proportion of patients } \\
\text { alive following treatment } \\
\text { with trametinib and I- } 124\end{array}$ & RAIRTC & August 2014 & Not mentioned \\
\hline Tipifarnib & NCT02383927 & II & ORR & $\begin{array}{l}\text { Relapsed or refractory to prior therapy TC with } \\
\text { missense HRAS mutation }\end{array}$ & March 2015 & December 2017 \\
\hline Vemurafenib & NCT01709292 & II & $\begin{array}{l}\text { Percent change in ERK } \\
\text { phosphorylation and } \\
\text { tumor size. Evaluate the } \\
\text { existence of correlation } \\
\text { between these two } \\
\text { variables }\end{array}$ & Locally advanced DTC requiring surgical treatment & November 2012 & November 2019 \\
\hline $\begin{array}{l}\text { Avelumab plus } \\
\text { checkpoint } \\
\text { agonist(s) with or } \\
\text { without RT or RT } \\
\text { plus cisplatin }\end{array}$ & NCT03217747 & $1 / 11$ & AEs & $\begin{array}{l}\text { Advanced TC refractory or intolerant to } \\
\text { established therapy known to provide clinical } \\
\text { benefit, or where subjects refuse existing } \\
\text { therapies }\end{array}$ & August 2017 & August 2022 \\
\hline $\begin{array}{l}\text { Cediranib maleate } \\
\text { with or without } \\
\text { lenalidomide }\end{array}$ & NCT01208051 & $1 / 11$ & $\begin{array}{l}\text { Maximum-tolerated dose } \\
\text { (Phase I); PFS (Phase II) }\end{array}$ & $\begin{array}{l}\text { RAIRTC with evidence of disease progression } \\
\text { within the last } 12 \text { months }\end{array}$ & September 2010 & September 2017 \\
\hline HuMax-AXL-ADC & NCT02988817 & $1 / 11$ & $\begin{array}{l}\text { Dose limiting toxicities; } \\
\text { AEs }\end{array}$ & $\begin{array}{l}\text { Relapsed, advanced or metastatic TC who have } \\
\text { failed available standard therapy or who are not } \\
\text { candidates for standard therapy }\end{array}$ & December 2016 & June 2021 \\
\hline Lenvatinib & NCT02432274 & $1 / 11$ & ORR & RAIRTC & December 2014 & September 2018 \\
\hline LOXO-195 & NCT03215511 & $1 / 11$ & $\begin{array}{l}\text { Maximum-tolerated dose } \\
\text { (Phase I); recommended } \\
\text { dose for further study } \\
\text { (Phase I); } \\
\text { best ORR (Phase II) }\end{array}$ & $\begin{array}{l}\text { TC with NTRK fusion treated with prior TRK } \\
\text { inhibitor or TC do not benefit greatly with other } \\
\text { standard or investigational therapies }\end{array}$ & July 2017 & December 2019 \\
\hline $\begin{array}{l}\text { Sacituzumab } \\
\text { govitecan }\end{array}$ & NCT01631552 & $1 / 11$ & Safety & $\begin{array}{l}\text { Metastatic FTC refractory to or relapsed after at } \\
\text { least one prior standard therapeutic regimen }\end{array}$ & February 2013 & June 2018 \\
\hline \multicolumn{7}{|c|}{$\begin{array}{l}\text { 99mTC HMDP: Technetium-99 hydroxymethylene diphosphonate; AE: Adverse event; CT: Computed tomography; DTC: Differentiated thyroid cancer; EAY131: National Cancer Institute } \\
\text { (NCI)-Molecular Analysis for Therapy Choice (MATCH); FDG: 8F-fluorodeoxyglucose; FTC: Follicular thyroid cancer; I-124: lodine-124; IMRT: Intensity-modulated radiation therapy; MTC: } \\
\text { Medullary thyroid cancer; NCI-MATCH: Molecularly matched therapy and have no further molecularly matched treatment recommendations per EAY131; ORR: Overall response rate; } \\
\text { OS: Overall survival; PERCIST: Positron emission tomography response criteria in solid tumor; PDTC: Poorly differentiated thyroid cancer; PFS: Progression-free survival; RAI: Radioiodine; } \\
\text { RAIRTC: Radioiodine refractory thyroid cancer; RECIST: Response evaluation criteria in solid tumor; RT: External beam radiation; TA: Total activity; TC: Thyroid cancer. }\end{array}$} \\
\hline
\end{tabular}

cells, natural killer cells and immune checkpoints [58-60]. Also, combination therapy of TKIs with other drugs such as immune checkpoint inhibitors is a matter of special interest [61].

Immune checkpoint inhibitors at the moment have the biggest role in this class since they are the novelty responsible for improving outcomes seen in other tumors such as melanoma [62]. A study of pembrolizumab in advanced solid tumors included 22 patients with advanced DTC who failed standard treatment and showed an 
Table 4. Details about Phase II-IV clinical trials enrolled at EU Clinical Trials Register which includes advanced differentiated thyroid cancer.

\begin{tabular}{|c|c|c|c|c|c|c|}
\hline Drug & EudraCT number & $\begin{array}{l}\text { Phase of } \\
\text { study }\end{array}$ & Primary outcomes & Patients & Time of start & $\begin{array}{l}\text { Estimated time } \\
\text { of completion }\end{array}$ \\
\hline Lenvatinib & $2010-023783-41$ & III & PFS & $\begin{array}{l}\text { RAIRTC with radiographic evidence of disease } \\
\text { progression within the prior } 12 \text { months }\end{array}$ & July 2011 & Not mentioned \\
\hline Sorafenib & $2009-012007-25$ & III & PFS & $\begin{array}{l}\text { Locally advanced/metastatic RAIRTC or PDTC not } \\
\text { candidates for surgery or RT with curative intent } \\
\text { and with evidence of progression within } \\
14 \text { months prior to enrollment }\end{array}$ & October 2009 & Not mentioned \\
\hline Sunitinib & $2006-006538-16$ & III & $\begin{array}{l}\text { Continue sunitinib } \\
\text { treatment }\end{array}$ & $\begin{array}{l}\text { TC subjects that have participated in a previous } \\
\text { parent or extension of sunitinib study and are } \\
\text { thought to have the potential to derive clinical } \\
\text { benefit from continued treatment }\end{array}$ & March 2017 & Not mentioned \\
\hline Vandetanib & $2013-000422-58$ & III & PFS & $\begin{array}{l}\text { Locally advanced or metastatic RAIRTC/PDTC not } \\
\text { amenable to surgical resection, RT or other local } \\
\text { therapy }\end{array}$ & July 2013 & Not mentioned \\
\hline Crizotinib & 2013-000885-13 & II & ORR & $\begin{array}{l}\text { Metastatic or unresectable locally advanced TC } \\
\text { with MET mutation considered by the } \\
\text { investigator as not amenable to any other } \\
\text { validated therapeutic option }\end{array}$ & July 2013 & 2019 \\
\hline $\begin{array}{l}\text { Dabrafenib plus } \\
\text { trametinib }\end{array}$ & 2013-001705-87 & II & ORR & $\begin{array}{l}\text { Advanced TC BRAF mutated with no available } \\
\text { standard treatment options }\end{array}$ & March 2014 & 2020 \\
\hline Everolimus & $2009-016669-27$ & II & Efficacy & $\begin{array}{l}\text { Irresectable recurrent or metastatic RAIRTC, ATC } \\
\text { and MTC with evidence of progression within } \\
\text { the } 14 \text { months before starting the therapy }\end{array}$ & April 2010 & Not mentioned \\
\hline Lenvatinib & $2007-005933-12$ & II & ORR & $\begin{array}{l}\text { Unresectable RAIRTC or MTC with evidence of } \\
\text { disease progression within the last } 12 \text { months } \\
\text { before starting the study }\end{array}$ & October 2009 & Not mentioned \\
\hline Lenvatinib & 2014-005199-27 & II & $\begin{array}{l}\text { Determine whether a } \\
\text { starting dose of } 20 \mathrm{mg} \text { or } \\
14 \mathrm{mg} \text { QD will provide } \\
\text { comparable efficacy with } \\
\text { an improved safety profile } \\
\text { compared with } 24 \text { mg QD }\end{array}$ & $\begin{array}{l}\text { RAIRTC showing progression of disease within } \\
12 \text { months before starting therapy }\end{array}$ & May 2016 & 2019 \\
\hline Nivolumab & $2016-000461-23$ & II & Clinical benefit rate & Advanced/metastatic RAIRTC & March 2017 & 2023 \\
\hline Nintedanib & 2012-004295-19 & II & PFS & $\begin{array}{l}\text { Locally advanced or metastatic DTC/MTC } \\
\text { deemed incurable by surgery, RT and/or RAI } \\
\text { with evidence of progression within } 12 \text { months } \\
\text { before starting the study }\end{array}$ & August 2014 & 2019 \\
\hline Pembrolizumab & 2016-002260-14 & II & ORR & $\begin{array}{l}\text { Unresectable locally advanced or metastatic } \\
\text { DTC, PDTC, MTC or ATC which are resistant or } \\
\text { refractory to standard therapy, or for which } \\
\text { standard therapy does not exist, or is not } \\
\text { considered appropriate, and for which no other } \\
\text { experimental treatment options are available }\end{array}$ & April 2017 & 2023 \\
\hline Pembrolizumab & $2015-002067-41$ & II & ORR & $\begin{array}{l}\text { Metastatic and/or unresectable DTC that is } \\
\text { incurable and for which prior standard first-line } \\
\text { treatment has failed }\end{array}$ & January 2016 & 2023 \\
\hline Selumetinib & 2013-000423-14 & II & $\begin{array}{l}\text { Complete remission rate in } \\
\text { the general population } \\
\text { and in patients harboring } \\
\text { BRAF or NRAS mutation }\end{array}$ & $\begin{array}{l}\text { DTC T3a-T4 or at least } 1 \text { lymph node that is } \\
\geq 1 \mathrm{~cm} \text { or } \geq 5 \text { involved lymph nodes (of any size) }\end{array}$ & May 2013 & 2017 \\
\hline Selumetinib & $2015-002269-47$ & II & PFS & Locally advanced or metastatic RAIRTC or PDTC & December 2015 & 2019 \\
\hline Sorafenib & $2006-006615-80$ & II & ORR & $\begin{array}{l}\text { Advanced or metastatic DTC or MTC not suitable } \\
\text { for RAI }\end{array}$ & February 2007 & Not mentioned \\
\hline Tipifarnib & $2015-004535-12$ & II & ORR & $\begin{array}{l}\text { HRAS mutation TC that has relapsed or is } \\
\text { refractory to prior therapy }\end{array}$ & February 2016 & 2018 \\
\hline $\begin{array}{l}\text { Trametinib plus } \\
\text { RAI } \\
\text { with/without } \\
\text { dabrafenib }\end{array}$ & $2017-000742-21$ & II & ORR & $\begin{array}{l}\text { Metastatic RAIRTC or PDTC with RAS or BRAF } \\
\text { mutation showing progression of disease within } \\
18 \text { months before starting the study }\end{array}$ & July 2017 & 2022 \\
\hline Vandetanib & 2007-001890-27 & II & PFS & Advanced or metastatic RAIRTC & June 2007 & Not mentioned \\
\hline
\end{tabular}




\begin{tabular}{|c|c|c|c|c|c|c|}
\hline Drug & EudraCT number & $\begin{array}{l}\text { Phase of } \\
\text { study }\end{array}$ & Primary outcomes & Patients & Time of start & $\begin{array}{l}\text { Estimated time } \\
\text { of completion }\end{array}$ \\
\hline Vemurafenib & 2014-001225-33 & $\|$ & Efficacy & $\begin{array}{l}\text { Unresectable locally advanced or metastatic TC } \\
\text { harboring BRAF mutations refractory to } \\
\text { standard therapy or for which standard or } \\
\text { curative therapy does not exist or is not } \\
\text { considered appropriate by the investigator and } \\
\text { are not eligible to an appropriate ongoing } \\
\text { clinical trial }\end{array}$ & July 2014 & 2021 \\
\hline $\begin{array}{l}\text { AZD2014 plus } \\
\text { selumetinib }\end{array}$ & 2014-002613-31 & $\mathrm{IB} / \mathrm{IIA}$ & $\begin{array}{l}\text { Establish the feasible dose } \\
\text { levels and regimens of } \\
\text { AZD2014 and selumetinib } \\
\text { when given in } \\
\text { combination }\end{array}$ & $\begin{array}{l}\text { Metastatic or locally advanced TC with } \\
\text { alteration in } \geq 1 \text { gene involved in } \\
\text { PISK/AKT/mTOR or Ras/MEK pathway signaling } \\
\text { which is not amenable to resection and } \\
\text { refractory to conventional treatment or for } \\
\text { which no conventional therapy exists }\end{array}$ & April 2015 & 2017 \\
\hline WX-554 & 2011-003408-19 & $1 / 11$ & $\begin{array}{l}\text { Determine the optimum } \\
\text { biological, the maximum } \\
\text { tolerated and the } \\
\text { recommended doses/dose } \\
\text { schedules (Phase I); } \\
\text { determine the safety and } \\
\text { tolerability of chronic } \\
\text { treatment }\end{array}$ & $\begin{array}{l}\text { Advanced, metastatic and/or progressive TC for } \\
\text { whom there is no effective standard therapy } \\
\text { available }\end{array}$ & January 2012 & Not mentioned \\
\hline
\end{tabular}

ATC: Anaplastic thyroid cancer; DTC: Differentiated thyroid cancer; MTC: Medullary thyroid cancer; ORR: Overall response rate; PDTC: Poorly differentiated thyroid cancer; PFS: Progression-free survival; QD: Once-daily; RAl: Radioiodine; RAIRTC: Radioiodine refractory thyroid cancer; RT: External beam radiation; TC: Thyroid cancer.

expression of PD-L1 $\geq 1 \%$ or stroma cell lines by immunohistochemistry. Preliminary results showed a $54.5 \%$ rate of stable disease, $9 \%$ rate of partial response, a 6 -month OS rate of $100 \%$ and a $58.7 \%$ rate of 6 -month PFS. Despite 18 patients had treatment-related $\mathrm{AE}$, none of the patients needed to discontinue the drug [62]. At clinicaltrials.gov and EU Clinical Trials Register there are several studies ongoing with these drugs, such as ipilimumab plus nivolumab (two Phase II studies), pembrolizumab plus lenvatinib (one Phase II study), pembrolizumab alone (three Phase II studies), nivolumab alone (one Phase II study) and avelumab plus checkpoint agonist(s) with or without irradiation or irradiation plus cisplatin (one Phase I/II study). So, in the next few years, we will probably be able to have evidence of the efficacy of these drugs in RAIRTC [46,47].

\section{Microtubule inhibitors}

CA4 is a naturally occurring inhibitor of tubulin that acts as an antimitotic agent, causing vascular shutdown and cell death. CA4 has already shown cytotoxic and antiproliferative activity in a variety of cancers. Recently, in a preclinical study using human thyroid papillary carcinoma cell line TPC1, CA4 showed the capacity to inhibit proliferation, migration and invasion and of promoting apoptosis. Due to these results, CA4 is considered a potential therapeutic target for the treatment of TC [63].

\section{Other investigational therapies}

New multi-TKIs (pyrazolopyrimidines and derivatives of CLM3) and other therapeutic classes such as inhibitors of aurora kinases, proteasome, kinesin spindle protein, cancer stem cells and histone deacetylases, flavonoids, gene and apoptotic cell death-based therapies have already shown promising results in preclinical studies, and may have a role in advanced TC therapy in the future [26-27,58-60,64-71].

Financial \& competing interests disclosure

H Simões has received logistic support (accommodation and travel support) from Bayer Healthcare company related to participation in Thyroid Cancer update sessions at Gustave Roussy Institute in Paris, October 2016. The authors have no other relevant affiliations or financial involvement with any organization or entity with a financial interest in or financial conflict with the subject matter or materials discussed in the manuscript apart from those disclosed.

No writing assistance was utilized in the production of this manuscript. 
Executive summary

- The majority of differentiated thyroid cancers have a good prognosis. A minority, however, will become refractory to radioiodine and progress with local recurrence and/or distant metastases.

- Conventional cytotoxic chemotherapy has been largely replaced by molecularly targeted therapies, but it can still be useful in some patients.

- Two tyrosine kinase inhibitors have been approved for the treatment of advanced differentiated thyroid cancer (sorafenib and lenvatinib). They significantly improve progression-free survival, but at the cost of frequent and potentially serious adverse effects and without clear benefit in overall survival.

- Other multitarget tyrosine kinase inhibitors are under investigation at the moment, some with good results in preclinical trials.

- Dabrafenib and selumetinib showed promising results in the redifferentiation of thyroid tumors.

- Association of sorafenib plus everolimus showed favorable results. The association of everolimus with other drugs (i.e., lenvatinib) is being studied.

- Other drug classes such as immune checkpoint inhibitors may also have therapeutic potential.

\section{Open access}

This work is licensed under the Creative Commons Attribution 4.0 License. To view a copy of this license, visit http://creativecomm ons.org/licenses/by/4.0/.

\section{References}

1. American Cancer Society. Cancer facts and figures (2015). www.cancer.org/research/cancer-facts- statistics.html

2. Chen AY, Jemal A, Ward EM. Increasing incidence of differentiated thyroid cancer in the United States, 1988-2005. Cancer 115(16), 3801-3807 (2009).

3. Ahn HS, Kim HJ, Welch HG. Korea's thyroid-cancer 'epidemic' - screening and overdiagnosis. N. Engl. J. Med. 371(19), 1765-1767 (2014).

4. Brito JP, Al Nofal A, Montori VM, Hay ID, Morris JC. The Impact of subclinical disease and mechanism of detection on the rise in thyroid cancer incidence: a population-based study in Olmsted County, Minnesota during 1935 through 2012. Thyroid 25(9), 999-1007 (2015).

5. Elisei R, Pinchera A. Advances in the follow-up of differentiated or medullary thyroid cancer. Nat. Rev. Endocrinol. 8(8), 466-475 (2012).

6. Smallridge RC, Copland JA. Anaplastic thyroid carcinoma: pathogenesis and emerging therapies. Clin. Oncol. (R. Coll. Radiol.), 22(6), 486-497 (2010).

7. Veiga LH, Neta G, Aschebrook-Kilfoy B, Ron E, Devesa SS. Thyroid cancer incidence patterns in Sao Paulo, Brazil, and the US SEER program, 1997-2008. Thyroid 23(6), 748-757 (2013).

8. Surov A, Gottschling S, Wienke A, Meyer HJ, Spielmann RP, Dralle H. Primary thyroid sarcoma: a systematic review. Anticancer Res. 35(10), 5185-5191 (2015).

9. Chai YJ, Hong JH, Koo do $\mathrm{H}$ et al. Clinicopathological characteristics and treatment outcomes of 38 cases of primary thyroid lymphoma: a multicenter study. Ann. Surg. Treat. Res. 89(6), 295-299 (2015).

10. Spitzweg C, Bible KC, Hofbauer LC, Morris JC. Advanced radioiodine-refractory differentiated thyroid cancer: the sodium iodide symporter and other emerging therapeutic targets. Lancet Diabetes Endocrinol. 2(10), 830-842 (2014).

11. Haugen BR, Alexander EK, Bible KC et al. 2015 American Thyroid Association Management Guidelines for adult patients with thyroid nodules and differentiated thyroid cancer: the American Thyroid Association Guidelines Task Force on thyroid nodules and differentiated thyroid cancer. Thyroid 26(1), 1-133 (2016).

12. Durante C, Haddy N, Baudin E et al. Long-term outcome of 444 patients with distant metastases from papillary and follicular thyroid carcinoma: benefits and limits of radioiodine therapy. J. Clin. Endocrinol. Metab. 91(8), 2892-2899 (2006).

13. Schlumberger $\mathrm{M}$, Brose $\mathrm{M}$, Elisei R et al. Definition and management of radioactive iodine-refractory differentiated thyroid cancer. Lancet Diabetes Endocrinol. 2(5), 356-358 (2014).

14. Albero A, Lopez JE, Torres A, de la Cruz L, Martin T. Effectiveness of chemotherapy in advanced differentiated thyroid cancer: a systematic review. Endocr. Relat. Cancer 23(2), R71-R84 (2016).

15. Matuszczyk A, Petersenn S, Bockisch A et al. Chemotherapy with doxorubicin in progressive medullary and thyroid carcinoma of the follicular epithelium. Horm. Metab. Res. 40(3), 210-213 (2008).

16. Hussein $\mathrm{O}$, Karen D, Zidan J. Cisplatin based chemotherapy in patients with advanced differentiated thyroid carcinoma refractory to I131 treatment. Indian J. Med. Paediatr. Oncol. 34(4), 234-237 (2013). 
17. Santini F, Bottici V, Elisei R et al. Cytotoxic effects of carboplatinum and epirubicin in the setting of an elevated serum thyrotropin for advanced poorly differentiated thyroid cancer. J. Clin. Endocrinol. Metab. 87(9), 4160-4165 (2002).

18. Spano JP, Vano Y, Vignot $S$ et al. GEMOX regimen in the treatment of metastatic differentiated refractory thyroid carcinoma. Med. Oncol. 29(3), 1421-1428 (2012).

19. Paris AP-Hd. Gemcitabine - oxaliplatin for advanced refractory thyroid cancer patients: a Phase II study (THYGEMOX). ClinicalTrials.gov (2016).

20. Integrated genomic characterization of papillary thyroid carcinoma. Cell 159(3), 676-690 (2014).

21. Xing M. Molecular pathogenesis and mechanisms of thyroid cancer. Nat. Rev. Cancer 13(3), 184-199 (2013).

22. Landa I, Ibrahimpasic T, Boucai $\mathrm{L}$ et al. Genomic and transcriptomic hallmarks of poorly differentiated and anaplastic thyroid cancers. J. Clin. Invest. 126(3), 1052-1066 (2016).

23. Ishiwata T, Iino Y, Takei H, Oyama T, Morishita Y. Tumor angiogenesis as an independent prognostic indicator in human papillary thyroid carcinoma. Oncol. Rep. 5(6), 1343-1348 (1998).

24. Klein M, Vignaud JM, Hennequin V et al. Increased expression of the vascular endothelial growth factor is a pejorative prognosis marker in papillary thyroid carcinoma. J. Clin. Endocrinol. Metab. 86(2), 656-658 (2001).

25. Lennard CM, Patel A, Wilson J et al. Intensity of vascular endothelial growth factor expression is associated with increased risk of recurrence and decreased disease-free survival in papillary thyroid cancer. Surgery 129(5), 552-558 (2001).

26. Ferrari SM, La Motta C, Sartini S et al. Pyrazolopyrimidine derivatives as antineoplastic agents: with a special focus on thyroid cancer. Mini Rev. Med. Chem. 16(2), 86-93 (2016).

27. Antonelli A, La Motta C. Novel therapeutic clues in thyroid carcinomas: the role of targeting cancer stem cells. Med. Res. Rev. 37(6), 1299-1317 (2017).

28. Bikas A, Vachhani S, Jensen K, Vasko V, Burman KD. Targeted therapies in thyroid cancer: an extensive review of the literature. Expert Rev. Clin. Pharmacol. 15, 1-15 (2016).

29. Lirov R, Worden FP, Cohen MS. The treatment of advanced thyroid cancer in the age of novel targeted therapies. Drugs 77(7), 733-745 (2017).

30. Cabanillas ME, Patel A, Danysh BP, Dadu R, Kopetz S, Falchook G. BRAF inhibitors: experience in thyroid cancer and general review of toxicity. Horm. Cancer 6(1), 21-36 (2015).

31. Viola D, Valerio L, Molinaro E et al. Treatment of advanced thyroid cancer with targeted therapies: ten years of experience. Endocr. Relat. Cancer 23(4), R185-R205 (2016).

32. Bible KC, Ryder M. Evolving molecularly targeted therapies for advanced-stage thyroid cancers. Nat. Rev. Clin. Oncol. 13(7), 403-416 (2016).

33. Carr LL, Mankoff DA, Goulart BH et al. Phase II study of daily sunitinib in FDG-PET-positive, iodine-refractory differentiated thyroid cancer and metastatic medullary carcinoma of the thyroid with functional imaging correlation. Clin. Cancer Res. 16(21), 5260-5268 (2010).

34. Bible KC, Suman VJ, Molina JR et al. Efficacy of pazopanib in progressive, radioiodine-refractory, metastatic differentiated thyroid cancers: results of a Phase II consortium study. Lancet Oncol. 11(10), 962-972 (2010).

35. Klein Hesselink EN, Steenvoorden D, Kapiteijn E et al. Therapy of endocrine disease: response and toxicity of small-molecule tyrosine kinase inhibitors in patients with thyroid carcinoma: a systematic review and meta-analysis. Eur. J. Endocrinol. 172(5), R215-R225 (2015).

36. Brose MS, Nutting CM, Jarzab B et al. Sorafenib in radioactive iodine-refractory, locally advanced or metastatic differentiated thyroid cancer: a randomised, double-blind, Phase III trial. Lancet 384(9940), 319-328 (2014).

37. Schlumberger M, Tahara M, Wirth LJ et al. Lenvatinib versus placebo in radioiodine-refractory thyroid cancer. N. Engl. J. Med. 372(7), 621-630 (2015).

38. Brose MS, Worden FP, Newbold KL, Guo M, Hurria A. Effect of age on the efficacy and safety of lenvatinib in radioiodine-refractory differentiated thyroid cancer in the Phase III SELECT trial. J. Clin. Oncol. 35(23), 2692-2699 (2017).

39. US Department Of Health And Human Services, National Institutes of Health, National Cancer Institute. Common Terminology Criteria for Adverse Events (CTCAE) (2010). https://evs.nci.nih.gov/ftp1/CTCAE/CTCAE_4.03_2010-06-14_QuickReference_5x7.pdf

40. Zamorano JL, Lancellotti P, Rodriguez Munoz D et al. 2016 ESC Position Paper on cancer treatments and cardiovascular toxicity developed under the auspices of the ESC Committee for Practice Guidelines: the Task Force for cancer treatments and cardiovascular toxicity of the European Society of Cardiology (ESC). Eur. Heart J. 37(36), 2768-2801 (2016).

41. Ancker OV, Wehland M, Bauer J, Infanger M, Grimm D. The adverse effect of hypertension in the treatment of thyroid cancer with multi-kinase inhibitors. Int. J. Mol. Sci. 18(3), pii:E625 (2017) (Epub ahead of print).

42. Califano R, Tariq N, Compton $S$ et al. Expert consensus on the management of adverse events from EGFR tyrosine kinase inhibitors in the UK. Drugs 75(12), 1335-1348 (2015). 
43. Aparicio-Gallego G, Blanco M, Figueroa A et al. New insights into molecular mechanisms of sunitinib-associated side effects. Mol. Cancer Ther. 10(12), 2215-2223 (2011).

44. Aw DC, Tan EH, Chin TM, Lim HL, Lee HY, Soo RA. Management of epidermal growth factor receptor tyrosine kinase inhibitor-related cutaneous and gastrointestinal toxicities. Asia Pac. J. Clin. Oncol. doi:10.1111/ajco.12687 (2017) (Epub ahead of print).

45. Massicotte $\mathrm{MH}$, Brassard $\mathrm{M}$, Claude-Desroches $\mathrm{M}$ et al. Tyrosine kinase inhibitor treatments in patients with metastatic thyroid carcinomas: a retrospective study of the TUTHYREF network. Eur. J. Endocrinol. 170(4), 575-582 (2014).

46. EU Clinical Trials Register (2017). www.clinicaltrialsregister.eu/

47. ClinicalTrials (2017). https://clinicaltrials.gov/

48. Brose MS, Cabanillas ME, Cohen EE et al. Vemurafenib in patients with BRAF(V600E)-positive metastatic or unresectable papillary thyroid cancer refractory to radioactive iodine: a non-randomised, multicentre, open-label, Phase II trial. Lancet Oncol. 17(9), 1272-1282 (2016).

49. Brose MS. Sequencing of tyrosine kinase inhibitors in progressive differentiated thyroid cancer. Clin. Adv. Hematol. Oncol. 14(Suppl. 9), 7-12 (2016).

50. Rothenberg SM, McFadden DG, Palmer EL, Daniels GH, Wirth LJ. Redifferentiation of iodine-refractory BRAF V600E-mutant metastatic papillary thyroid cancer with dabrafenib. Clin. Cancer Res. 21(5), 1028-1035 (2015).

51. Falchook GS, Millward M, Hong D et al. BRAF inhibitor dabrafenib in patients with metastatic BRAF-mutant thyroid cancer. Thyroid 25(1), 71-77 (2015).

52. Chow LQ, Santana-Davila R, Pantel A et al. A Phase I study of pazopanib in combination with escalating doses of 131I in patients with well-differentiated thyroid carcinoma borderline refractory to radioiodine. PLoS ONE 12(6), e0178325 (2017).

53. AstraZeneca. Study comparing complete remission after treatment with selumetinib/placebo in patient with differentiated thyroid cancer (ASTRA). ClinicalTrials.gov Identifier: NCT01843062 (2017). https://clinicaltrials.gov/ct2/show/NCT01843062

54. United AaCCR. Iodine I-131 with or without selumetinib in treating patients with recurrent or metastatic thyroid cancer. ClinicalTrials.gov Identifier: NCT02393690 (2017). https://clinicaltrials.gov/ct2/show/NCT02393690

55. Schneider TC, de Wit D, Links TP et al. Everolimus in patients with advanced follicular-derived thyroid cancer: results of a Phase II clinical trial. J. Clin. Endocrinol. Metab. 102(2), 698-707 (2017).

56. Kelly LM, Barila G, Liu P et al. Identification of the transforming STRN-ALK fusion as a potential therapeutic target in the aggressive forms of thyroid cancer. Proc. Natl Acad. Sci. USA 111(11), 4233-4238 (2014).

57. Zhou Y, Zhao C, Gery S et al. Off-target effects of c-MET inhibitors on thyroid cancer cells. Mol. Cancer Ther. 13(1), 134-143 (2014).

58. Bastman JJ, Serracino HS, Zhu Y et al. Tumor-infiltrating T cells and the PD-1 checkpoint pathway in advanced differentiated and anaplastic thyroid cancer. J. Clin. Endocrinol. Metab. 101(7), 2863-2873 (2016).

59. French JD, Bible K, Spitzweg C, Haugen BR, Ryder M. Leveraging the immune system to treat advanced thyroid cancers. Lancet Diabetes Endocrinol. 5(6), 469-481 (2017).

60. Parhar RS, Zou M, Al-Mohanna FA et al. IL-12 immunotherapy of Braf(V600E)-induced papillary thyroid cancer in a mouse model. Lab. Invest. 96(1), 89-97 (2016).

61. Ito $\mathrm{Y}$, Suzuki S, Ito $\mathrm{K}$ et al. Tyrosine-kinase inhibitors to treat radioiodine-refracted, metastatic, or recurred and progressive differentiated thyroid carcinoma. Endocr. J. 63(7), 597-602 (2016).

62. Cunha LL, Marcello MA, Rocha-Santos V, Ward LS. Immunotherapy against endocrine malignancies: immune checkpoint inhibitors lead the way. Endocr. Relat. Cancer pii:ERC-17-0222 (2017) (Epub ahead of print).

63. Liang W, Lai Y, Zhu M, Huang S, Feng W, Gu X. Combretastatin A4 regulates proliferation, migration, invasion, and apoptosis of thyroid cancer cells via PI3K/Akt signaling pathway. Med. Sci. Monit. 22, 4911-4917 (2016).

64. Baldini E, Tuccilli C, Prinzi N et al. Selective inhibitors of aurora kinases inhibit proliferation, reduce cell viability and impair cell cycle progression in papillary thyroid carcinoma cells. J. Biol. Regul. Homeost. Agent 29(4), 793-803 (2015).

65. Quagliariello V, Armenia E, Aurilio C et al. New treatment of medullary and papillary human thyroid cancer: biological effects of hyaluronic acid hydrogel loaded with quercetin alone or in combination to an inhibitor of aurora kinase. J. Cell. Physiol. 231(8), 1784-1795 (2016).

66. Sui GQ, Fei D, Guo F et al. MicroRNA-338-3p inhibits thyroid cancer progression through targeting AKT3. Am. J. Cancer Res. 7(5), 1177-1187 (2017).

67. Celano M, Mio C, Sponziello M et al. Targeting post-translational histone modifications for the treatment of non-medullary thyroid cancer. Mol. Cell. Endocrinol. pii:S0303-7207(17)30305-2 (2017) (Epub ahead of print).

68. Broecker-Preuss M, Becher-Boveleth N, Muller S, Mann K. The BH3 mimetic drug ABT-737 induces apoptosis and acts synergistically with chemotherapeutic drugs in thyroid carcinoma cells. Cancer Cell Int. 16, 27 (2016).

69. Hussain AR, Bu R, Ahmed M et al. Role of X-linked inhibitor of apoptosis as a prognostic marker and therapeutic target in papillary thyroid carcinoma. J. Clin. Endocrinol. Metab. 100(7), E974-E985 (2015). 
70. Infante JR, Patnaik A, Verschraegen CF et al. Two Phase I dose-escalation studies exploring multiple regimens of litronesib (LY2523355), an Eg5 inhibitor, in patients with advanced cancer. Cancer Chemother. Pharmacol. 79(2), 315-326 (2017).

71. Mutlu Altundag E, Kasaci T, Yilmaz AM et al. Quercetin-induced cell death in human papillary thyroid cancer (B-CPAP) cells. J. Thyroid Res. 2016, 9843675 (2016). 
